\title{
Experimental transmission of Sphaerospora renicola to common carp Cyprinus carpio fry
}

\author{
Gerd Großheider, Wolfgang Körting
}

Fish Diseases Research Unit, School of Veterinary Medicine, Bünteweg 17, D-30559 Hannover, Germany

\begin{abstract}
The causative agent of renal sphaerosporosis and swimbladder inflammation was observed in specific-pathogen-free (SPF) carp Cyprinus carpio L. of the year following exposure to filtered water from a pond where Sphaerospora renicola Dykova et Lom, 1982 is enzootic. SPF carp showed infected kidney tubules after contact with water filtrates containing particles $<45 \mu \mathrm{m}$ in diameter. Using a Polymon filter the operative diameter of the causative agent could be determined as being $<20 \mu \mathrm{m}$ as shown by distinct $S$. renicola infections in SPF carp after exposure to $20 \mu \mathrm{m}$ filtrate. Previous reports of a direct infection by contact with spore-releasing donor carp or feeding on spore-containing kidney tissue could not be confirmed. It is hypothesized that an actinospore component may be the causative agent of $S$. renicola infections in common carp.
\end{abstract}

\section{INTRODUCTION}

Since Wolf \& Markiw (1984) reported results of infection trials to elucidate the life cycle of Myxobolus (Myxosoma) cerebralis and revealed an actinosporean as the infective organism of whirling disease of salmonids, a new model of the myxosporean life cycle including a corresponding actinosporean has become increasingly accepted. The results of experiments on transmission of other myxosporeans performed by several authors (El-Matbouli \& Hoffmann 1989, Hedrick et al. 1989, Kent et al. 1991, Ruidisch et al. 1991, El-Matbouli et al. 1992, Großheider \& Körting 1992) have supported this new idea of a common life cycle for formerly separated species of the divided classes of the phylum Myxozoa Grassé, 1960.

The aim of the present study was to clarify whether the new model could be applied to the life cycle of Sphaerospora renicola Dykova et Lom, 1982, the causative myxosporean of swimbladder inflammation (SBI) of common carp Cyprinus carpio L. fry, or whether, as an alternative hypothesis, carp fry become infected directly by uptake of $S$. renicola spores. With reference to the results of Wolf \& Markiw (1984) it seems to be impossible to exclude a priori any organism living in the pond environment as an intermediate or second host. Therefore we divided the field of work into looking at the pond substrate, investigations on the pond water body, and tests on invertebrates such as molluscs and oligochaetes.

The present paper reports results of experiments on material derived from the water after filtration, and of trials in which acceptor common carp were exposed to kidney tissue containing $S$. renicola spores or to aquarium water contaminated with spores.

\section{MATERIALS AND METHODS}

Acceptor common carp Cyprinus carpio L. Specificparasite-free carp fry (SPF carp) from a laboratorybred stock ranging from 25 to $50 \mathrm{~mm}$ in length were used as acceptor carp in all experiments. The experiments were performed in thoroughly cleaned aquaria using tap water. Kidney samples from exposed acceptor carp were examined as fresh preparations and (if necesssary) as smears stained with Giemsa's.

Trials with infected donor carp. All donor carp used in this series of experiments originated from a farm pond in Lower Saxony (NW Germany) which harboured Sphaerospora renicola infected carp with a prevalence of about 80 to $100 \%$. 
Two series of experiments were carried out to test Sphaerospora renicola infection of carp fry by spore uptake:

During the first set of experiments (Table 1A) donor carp (Trial nos. 5-89 \& 14-89) and acceptor carp were kept together in the same aquarium. In further trials, kidney tissues of groups of 8 to 12 highly infected, spore-containing donor carp were pooled and fed in equal portions to between 4 and 11 groups of 2 acceptor carp each in $400 \mathrm{ml}$ glasses (nos. 15-89, 21-89, 22-89 $\& 08-90$ ). Acceptor carp were then combined $36 \mathrm{~h}$ later and kept in 1 aquarium.

In the second series (Table 1B) acceptor carp were maintained in contaminated aquaria where donor carp had previously been kept for 57 (no. 20-89) and 62 (no, 7-90) days. In this series aquarium water was not renewed after removing donor carp.

Trials with planktonic material. In 1990 and 1991, planktonic material was obtained by filtration of pond water from the same pond as before. Volumes of 1300 to 1500 I were taken weekly $50 \mathrm{~cm}$ below the surface of the pond water from the 2 nd to the 7 th week after hatching of the carp fry. The water was passed sequentially through a set of stacked PVC screens with mesh sizes of $630,300,212,125$ and $45 \mu \mathrm{m}$. Resuspended material collected from these screens was divided into a sample fixed with $4 \%$ formalin for diagnostic purposes and into material for infection experiments. In addition, after passing through the $45 \mu \mathrm{m}$ screen the final filtrate was used in an infection experiment.

Three further infection experiments using filtrates of volume 160 to $180 \mathrm{l}$ which passed first through screens of $45 \mu \mathrm{m}$ and subsequently through a $20 \mu \mathrm{m}$ Polymon mesh were carried out in a Sartorius filter holder. The $20 \mu \mathrm{m}$ filter meshes, covered with trapped material, were also exposed to SPF carp to test the infectivity of the collected material.

\section{RESULTS}

\section{Trials with infected donor carp}

In experiments carried out to test the infectivity of Sphaerospora renicola spores directly taken up by ac-

Table 1. Sphaerospora renicola infecting Cyprinus carpio. Infection trials without second host. SPF: specific-pathogen-free carp

\begin{tabular}{|c|c|c|c|c|}
\hline \multicolumn{5}{|c|}{ A. No time interval after releasing spores } \\
\hline Trial no. & Exposure to & $\begin{array}{l}\text { SPF } \\
\text { total }\end{array}$ & $\begin{array}{l}\text { Day no. of exposure } \\
\text { First/last sample }\end{array}$ & $\begin{array}{l}\text { Observation of } \\
\text { S. renicola, SBI }\end{array}$ \\
\hline $5-89$ & $\begin{array}{l}\text { Donor carp } \\
\text { separated by net }\end{array}$ & 27 & $13 / 71$ & None \\
\hline $14-89$ & $\begin{array}{l}\text { Donor carp } \\
\text { not separated }\end{array}$ & 8 & $30 / 40$ & None \\
\hline $15-89$ & $\begin{array}{l}\text { Homogen. kidney } \\
\text { of donor carp }\end{array}$ & 10 & $28 / 36$ & None \\
\hline $21-89$ & $\begin{array}{l}\text { Homogen. kidney } \\
\text { of donor carp }\end{array}$ & 16 & $60 / 89$ & None \\
\hline $22-89$ & $\begin{array}{l}\text { Homogen. kidney } \\
\text { of donor carp }\end{array}$ & 21 & $69 / 94$ & None \\
\hline $8-90$ & $\begin{array}{l}\text { Homogen. kidney } \\
\text { of donor carp }\end{array}$ & 7 & $63 / 114$ & None \\
\hline \multicolumn{5}{|c|}{ B. Subsequent exposure after keeping donor carp in aquaria } \\
\hline Trial no. & Tank contamination & $\begin{array}{l}\text { SPF } \\
\text { total }\end{array}$ & $\begin{array}{l}\text { Day no. of exposure } \\
\text { First/last sample }\end{array}$ & $\begin{array}{l}\text { Observation of } \\
\text { S. renicola, SBI }\end{array}$ \\
\hline $20-89$ & $\begin{array}{l}29 \text { donor carp for } \\
57 \text { d in } 60 l^{\mathrm{a}} \\
\text { replaced by SPF carp }\end{array}$ & 76 & $55 / 232$ & None \\
\hline $7-90$ & $\begin{array}{l}26 \text { donor carp for } \\
62 \text { d in } 60 \mathrm{~J}^{\mathrm{a}} \\
\text { replaced by SPF carp }\end{array}$ & 10 & $63 / 86$ & None \\
\hline${ }^{\circ}$ Tank vol & & & & \\
\hline
\end{tabular}


ceptor carp, all of the kidney samples of acceptor carp were negative in microscopical examinations (Table 1). None of the total of 54 SPF carp fed on spore-containing donor carp kidney tissue showed symptoms of either SBI or developmental stages of myxosporeans when dissected and examined microscopically (Table 1A). No renal sphaerosporosis developed in the $39 \mathrm{SPF}$ carp which were kept together with donor carp in the same tank or in the 83 SPF carp which were kept subsequently (Table $1 \mathrm{~B}$ ) in contaminated aquaria.

\section{Trials with planktonic material}

None of the experiments using material collected on PVC screens with mesh sizes ranging from 45 to $630 \mu \mathrm{m}$ led to Sphaerospora renicola infected carp or to swim- bladder inflammation in SPF carp, as shown by macroscopical and microscopical examinations (Table 2). Therefore species determination of planktonic organisms fixed in $4 \%$ formalin was not carried out.

In contrast, all infection experiments using filtrates which passed through the $45 \mu \mathrm{m}$ screen were successful in the transmission of Sphaerospora renicola to SPF carp (Table 3), and established low to middle degree infections.

The filtrate containing particles $<45 \mu \mathrm{m}$ yielded, in addition to sporoblasts, spores of Sphaerospora renicola and SBI. In this test 20 out of 30 carp were infected, 6 showed spores and 5 showed typical signs of SBI in macroscopical examinations. In addition developmental stages of $S$. renicola ('K-cells') could be observed in Giemsa-stained smears from infected swimbladders (Table 3).

Table 2. Sphaerospora renicola infecting Cyprinus carpio. Infection trials with planktonic material, collected from pond water

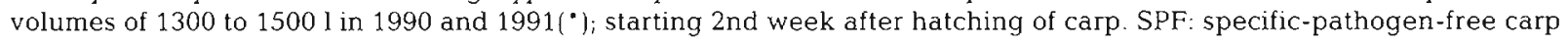

\begin{tabular}{|c|c|c|c|c|c|}
\hline Week $^{a}$ & $\begin{array}{l}\text { Mesh } \\
(\mu \mathrm{m})\end{array}$ & $\begin{array}{l}\text { SPF } \\
\text { total }\end{array}$ & $\begin{array}{l}\mathrm{SPF} / \\
50 \mathrm{~d}^{\mathrm{b}}\end{array}$ & $\begin{array}{l}\text { Day no. of exposure } \\
\text { First/last sample }\end{array}$ & $\begin{array}{c}\text { Observations of } \\
\text { SBI, sphaerosporosis }\end{array}$ \\
\hline \multirow{5}{*}{2} & 45 & 30 & 16 & $29 / 126$ & \multirow{5}{*}{ None } \\
\hline & 45 & 13 & 8 & $28 / 56^{\circ}$ & \\
\hline & 125 & 32 & 16 & $28 / 113$ & \\
\hline & 212 & 12 & 8 & $29 / 56^{\circ}$ & \\
\hline & 300 & 11 & 8 & $28 / 54^{\circ}$ & \\
\hline \multirow{5}{*}{3} & 45 & 50 & 22 & $24 / 140$ & \multirow{5}{*}{ None } \\
\hline & 125 & 49 & 22 & $23 / 72$ & \\
\hline & 125 & 12 & 8 & $28 / 57^{*}$ & \\
\hline & 212 & 13 & 8 & $28 / 57^{\circ}$ & \\
\hline & 300 & 12 & 8 & $28 / 56^{*}$ & \\
\hline \multirow{8}{*}{4} & 45 & 35 & 29 & $22 / 76$ & \multirow{8}{*}{ None } \\
\hline & 45 & 9 & 8 & $28 / 55^{*}$ & \\
\hline & 125 & 26 & 23 & $21 / 71$ & \\
\hline & 125 & 12 & 7 & $28 / 55^{\circ}$ & \\
\hline & 212 & 10 & 7 & $28 / 55^{\circ}$ & \\
\hline & 300 & 39 & 27 & $21 / 76$ & \\
\hline & 300 & 11 & 8 & $28 / 55^{\circ}$ & \\
\hline & 630 & 19 & 15 & $21 / 65$ & \\
\hline \multirow{4}{*}{5} & 45 & 23 & 20 & $30 / 133$ & \multirow{4}{*}{ None } \\
\hline & 125 & 35 & 21 & $29 / 132$ & \\
\hline & 300 & 30 & 25 & $30 / 133$ & \\
\hline & 630 & 23 & 20 & $30 / 140$ & \\
\hline \multirow{5}{*}{6} & 45 & 16 & 14 & $31 / 148$ & \multirow{5}{*}{ None } \\
\hline & 125 & 21 & 15 & $30 / 97$ & \\
\hline & 212 & 21 & 15 & $30 / 131$ & \\
\hline & 300 & 24 & 15 & $30 / 135$ & \\
\hline & 630 & 25 & 16 & $30 / 147$ & \\
\hline \multirow{4}{*}{7} & 45 & 15 & 11 & $26 / 79$ & \multirow{4}{*}{ None } \\
\hline & 125 & 18 & 15 & $37 / 83$ & \\
\hline & 212 & 21 & 14 & $38 / 83$ & \\
\hline & 300 & 16 & 13 & $38 / 84$ & \\
\hline
\end{tabular}


Table 3. Sphaerospora renicola infecting Cyprinus carpio. Infection trials with filtrates of pond water containing particles $<45 \mu \mathrm{m}$ in diameter, volumes 160 to 180 l. SPF: specific-pathogen-free carp

\begin{tabular}{|c|c|c|c|c|c|c|}
\hline Week $^{2}$ & $\begin{array}{l}\text { Mesh } \\
(\mu \mathrm{m})\end{array}$ & $\begin{array}{l}\text { SPF } \\
\text { total }\end{array}$ & $\begin{array}{l}\text { Day no. of exp. } \\
\text { First/last sample }\end{array}$ & $\begin{array}{c}\text { Kidneys } \\
\text { Total }\end{array}$ & $\begin{array}{l}\text { infected } \\
\text { Spores }\end{array}$ & $\begin{array}{c}\text { SBI } \\
\mathrm{m}^{\mathrm{b}} / \mathrm{K}^{\mathrm{c}}\end{array}$ \\
\hline 8 & $<45$ & 30 & $22 / 126$ & 20 & 8 & $5 / 5$ \\
\hline 13 & $<45,>20$ & 40 & $21 / 61$ & 9 & 0 & $0 / 0$ \\
\hline 13 & $<20$ & 42 & $21 / 77$ & 17 & 7 & $6 / 4$ \\
\hline 13 & $<20$ & 37 & $21 / 54$ & 13 & 4 & $3 / 3$ \\
\hline $\begin{array}{l}\text { a Week } \\
{ }^{\circ} \text { Macro } \\
{ }^{c} \mathrm{~K} \text {-cells }\end{array}$ & \multicolumn{2}{|c|}{$\begin{array}{l}\text { 'Macroscopically } \\
\text { cK }\end{array}$} & mears & & & \\
\hline
\end{tabular}

In our investigations we tried to confirm Odening et al.'s results, following his time schedule of sampling kidney tissue of acceptor carp, but our efforts to induce Sphaerospora renicola infections failed (Table 1A, B).

\section{Trials with planktonic material}

The water used for infection experiments was obtained from a wellstudied pond, where the course of Sphaerospora renicola infections in common carp populations hatched at the farm has been monitored since

Kidneys obtained from SPF carp exposed to $20 \mu \mathrm{m}$ Polymon meshes showed cells and cell groups with typical myxosporean features with a prevalence of 9 carp out of 40 . However these were rarely detectable in Giemsa-stained smears and in this experiment it was not possible to demonstrate Sphaerospora renicola spores or inflamed swimbladders in the acceptor carp.

In the 2 tests using water containing particles with an operative diameter $<20 \mu \mathrm{m}$, SPF carp developed Sphaerospora renicola infections at prevalences of 17 carp out of 42 and 13 carp out of 37 respectively; $S$. renicola spores and sporoblasts were observed. In addition, in both experiments some SPF carp showed macroscopically an inflammation of the swimbladder and ' $\mathrm{K}$-cells' in Giemsa-stained preparations (Table 3).

\section{DISCUSSION}

\section{Trials with infected donor carp}

The first series of infection trials sought to confirm both the direct life cycle of myxosporeans commonly understood before Wolf \& Markiw (1984) reported the first actinosporean/myxosporean model, and the results of Odening et al. (1989), who reported several successful transmissions of Sphaerospora renicola without a second host.

In tests carried out by Odening et al. (1989), acceptor carp were kept either together with donor carp harbouring Sphaerospora renicola spores, or in aquaria where infected carp had previously been kept. In further tests, acceptor carp were fed on $S$. renicola infected kidney tissue. In Odening et al.'s experiments acceptor carp infected with $S$. renicold spores were obtained. Spores were detected $10 \mathrm{wk}$ or more after starting the tests, with low prevalences of 1 carp out of 14,3 carp out of 16 , and 2 carp out of 22 respectively for the 3 types of test.
1979. Biffar (1990) reported that $S$. renicola infections became apparent in carp originating from this pond from the 5 th to 6 th week and spores were detectable from the 7 th to 8 th week after hatching. These results correspond to those of several other authors (Körting \& Hermanns 1984, Grupcheva et al. 1985, Odening et al. 1989). In 1990 Meyer (1991) determined the time interval until the sphaerosporosis-causing agent had infected carp fry in the monitored pond as 16 to $18 \mathrm{~d}$ after hatching. Thus in 1990 the causative agent of $S$. renicola infections must have been abundant in the farm pond in the $3 \mathrm{rd}$ to 7 th weeks after hatching of carp.

For these reasons filtration of pond water was started in the 2 nd week after hatching when a high level of infectivity could be expected. The negative results of infection trials using material collected on screens with mesh sizes $>45 \mu \mathrm{m}$ could not be explained by an insufficient water volume (1300 to 1500 l) because the positive results of infection trials using planktonic material with effective diameters $<45 \mu \mathrm{m}$ prove that pond water volumes of 160 to 180 l contain sufficient infective agents. Therefore the reason that the causative agent of Sphaerospora renicola infections was not trapped on the screens with meshes ranging from 45 to $630 \mu \mathrm{m}$ in size is clearly that the agent is $<45 \mu \mathrm{m}$ in diameter

Experiments with filtrates which had passed through membranes with mesh size $20 \mu \mathrm{m}$ led to a distinct Sphaerospora renicola infection and in several cases to SBI and therefore proved that the size of the operative diameter of the causative agent of SBI is $<20 \mu \mathrm{m}$. These data correspond to the work of Hedrick et al. (1992) who demonstrated that water apparently containing the causative agent ( $\mathrm{PKX}$ ) of proliferative kidney disease (PKD) was infective to Oncorhynchus mykiss after filtration through a screen with a mesh size of $50 \mu \mathrm{m}$. Thus an operative diameter $<50 \mu \mathrm{m}$ for the PKX organism was assumed

In spite of the size of the spore of Sphaerospora renicola, ranging from 6 to $8 \mu \mathrm{m}$ in diameter, the results of 
the experiments on direct infection make it improbable that $S$. renicola infections in a pond are caused by a planktonic $S$. renicola spore. Moreover the density of some myxosporean spores has been determined at $>1.0 \mathrm{~g} \mathrm{ml}^{-1}$, e.g. $1.062 \mathrm{~g} \mathrm{ml}^{-1}$ for Henneguya doori (McConnell \& Cone 1992) or $1.080 \mathrm{~g} \mathrm{ml}^{-1}$ for Myxobolus cerebralis (Hamilton \& Canning 1988). This causes the spores to settle to the bottom of the pond and is therefore in contradiction to the idea of a planktonic myxosporean spore.

Recently an increasing number of myxosporean species have had an oligochaete revealed as a second host in their life cycle, thus actinosporeans parasitizing these oligochaetes may be a phase of the myxosporean development (Wolf \& Markiw 1984, El-Matbouli \& Hoffmann 1989). This even includes species of the genus Hoferellus (El-Matbouli \& Hoffmann 1992. Großheider \& Körting 1992) which belong to the family Sphaerosporidae Davis, 1917 (Lom 1986).

Bearing in mind these observations, an actinosporean spore released from an unknown oligochaete could be expected to be the causative agent of Sphaerospora renicola infections. However, known actinosporean spores are $>20 \mu \mathrm{m}$ in diameter so it is difficult to imagine that a complete actinosporean spore is the planktonic agent of the $S$. renicola infection.

Following the myxosporean/actinosporean model it seems useful to look for a smaller component of the actinospore such as the sporoplasms located in the epispore and found in the skin of rainbow trout Oncorhynchus mykiss at the beginning of invasion by Myxobolus cerebralis (Markiw 1989). By comparison, Marques \& Ormieres (1982) observed disintegration of the spores of Synactinomyxon longicauda (Myxozoa: Actinosporea) and the spontaneous releasing of numerous sporoplasms after leaving its oligochaete host and contacting the surrounding water. Thus the sporoplasm of an unknown actinosporean should be considered as a hypothetical planktonic agent of Sphaerospora renicola infections of common carp fry.

Acknowledgements. We thank Mr S. H. Leenstra, Experimental Fish Facilities, Zodiac, Agriculture University Wageningen, The Netherlands, for providing fertilized carp eggs; and Mr H.J. Heese, Aschauteiche, Lower Saxony, Germany, for providing donor carp and water filtration facilities. This study was supported by DFG grant \# KO 384/10-1.

\section{LITERATURE CITED}

Biffar, M. (1990). Die Parasiten des Karpfens (Cyprinus carpio L.) im Jahreszyklus unter besonderer Berücksichtigung von Sphaerospora renicola in einer Karpfenteichwirtschaft in Ostniedersachsen. Doctoral thesis, School of Veterinary Medicine, Hannover
El-Matbouli, M., Fischer-Scherl, Th., Hoffmann, R. W. (1992). Transmission of Hoferellus carassii Achmerov, 1960 to goldfish Carassius auratus via an aquatic oligochaete. Bull. Eur. Ass. Fish Pathol. 12(2): $54-56$

El-Matbouli, M., Hoffmann, R. W. (1989). Experimental transmission of two Myxobolus spp. developing bisporogony via tubificid worms. Parasitol. Res. 75: 461-464

Großheider, G., Körting, W. (1992). First evidence that Hoferellus cyprini (Doflein, 1898) is transmitted by Nais sp. Bull. Eur. Ass. Fish Pathol. 12(1): 17-20

Grupcheva, G., Dykova, I., Lom, J. (1985). Seasonal fluctuation in the prevalence of Sphaerospora renicola and myxosporean bloodstream stages in carp fingerlings in Bulgaria. Folia Parasitol. (Praha) 32: 193-203

Hamilton, A. J., Canning, E. U. (1988). The production of antiMyxosoma cerebralis antiserum from Percoll-purified spores and its use in immunofluorescent labelling of Historesin-embedded cartilage derived from infected rainbow trout, Salmo gairdneri Richardson. J. Fish Dis. 11: $185-190$

Hedrick, R. P., Monge, D., de Kinkelin, P. (1992). Transmission of $\mathrm{PKX}$, the causative agent of proliferative kidney disease (PKD), to rainbow trout Oncorhynchus mykiss following filtration of water and sediments. Dis. aquat. Org. 14: $237-240$

Hedrick, R. P., Wishkovsky, A., Groff, J. M., McDowell, T. (1989). Transmission trials with three myxosporeans of salmonid fish. Abstract. In: Diseases of fish and shellfish. IV. EAFP International Conference, Santiago de Compostela, Spain, Sep. 24-28, 1989, p. 38

Kent, M. L., Whitacker, D. J., Margolis, L. (1991). Experimental transmission of the myxosporean Myxobolus arcticus to sockeye salmon using an aquatic oligochaete, Eclipidrilus sp. (Lumbriculidae). Am. Fish. Soc. Newslett. (Fish Health Sect.) 18(4): 4-5

Körting, W., Hermanns, W. (1984). Myxosporidien-Infektionen in der Niere des Karpfens (Cyprinus Carpio L.) aus niedersächsischen Teichwirtschaften. Berl. Münch. Tierärztl. Wochenschr. 97: 255-259

Lom, J. (1986). Hoferellus cyprini (Doflein, 1898) Berg, 1898 (syn. Mitraspora cyprini Fujita, 1912), Myxobilatus nostalgicus sp. n. and related species: partial revision of two myxosporean genera. Folia Parasitol. 33: 289-296

Markiw, M. E. (1989). Portals of entry for salmonid whirling disease in rainbow trout. Dis. aquat. Org. 6:7-10

Marques, A., Ormieres, R. (1982). La spore des Actinomyxidies: Synactinomyxon longicauda n. sp., un nouveau type de groupement sporal et adaptations planctoniques: émission et structure du sporoplasme. J. Protozool. 29: 195-202

McConnell, C. J., Cone, D. K. (1992). Settling rates and density of Henneguya doori (Myxosporea) in water. J. Parasitol. 78: 427-429

Meyer, J. (1991). Untersuchungen zum Entwicklungszyklus von Sphaerospora renicola (Myxozoa). Doctoral thesis, School of Veterinary Medicine, Hannover

Odening, K., Walter, G., Bockhardt, I. (1989). Zum Infektionsgeschehen bei Sphaerospora renicola (Myxosporidia). Angew. Parasitol. 30: 131-140

Ruidisch, S., El-Matbouli, M., Hoffmann, R. W. (1991). The role of tubificid worms as an intermediate host in the life cycle of Myxobolus pavlovskii (Akhmerov, 1954). Parasitol. Res. 77: 663-667

Wolf, K., Markiw, M. E. (1984). Biology contravenes taxonomy in the Myxozoa: new discoveries show alternation of invertebrate and vertebrate hosts. Science 225: 1449-1452 